DOI: $10.32481 / \mathrm{djph} .2021 .07 .017$

\title{
Medical Respite Programs for People who Experience Homelessness
}

\author{
Danielle Cooper
}

Intern, Delaware Academy of Medicine/Delaware Public Health Association; Graduate Student, University of Arizona

\section{Introduction}

A gap analysis was completed during my internship with the Delaware Academy of Medicine/Delaware Public Health Association (Academy/DPHA). During the gap analysis it was discovered there were no medical respite programs in Delaware for people who experience homelessness. This gap was chosen because there are outcomes via program intervention that show a decrease in hospital admissions, inpatient days, decrease in hospital costs, outpatient visits and increase social services for homeless individuals.

A medical respite program for people who experience homelessness aligns with the Academy/DPHA mission because one focus of the organization is community health planning and policy development. ${ }^{1}$ Utilizing a homeless medical respite program will allow people who experience homelessness in Delaware to have a safe place to recover from a hospital stay.

\section{Literature Review}

The exact number of people who experience homelessness in Delaware changes daily but on average there are over 900 individuals. ${ }^{2}$ Medical issues are increased if a person is experiencing homelessness, and treatment of any of those conditions is hard when there is a lack of stability or a safe environment. ${ }^{3}$ With nowhere to properly heal, the only options are to keep homeless individuals hospitalized or discharge them, potentially to not recover from their illness or injury. This leads to increased costs for hospital admissions, increased admission days and increased hospital admissions. ${ }^{3}$

\section{Medical Respite Programs}

Medical respite programs for people who experience homelessness are operational in several different settings such as apartments/motel rooms, standalone facilities, shelters, and assisted living centers across the United States. ${ }^{4}$ These facilities can have doctors, nurse practitioners, social workers, or case workers, depending on the setup. ${ }^{4}$ Using available information in the database, the median bed number in these facilities is 17 , and average length of stay for each client is 28 days. ${ }^{4}$ This program addresses the problems like increased cost for hospital admission, increased admission days, and increased hospital admission that people who experience homelessness can face when seeking medical care.

\section{What does a Medical Respite Program Provide?}

Medical respite programs have saved $\$ 1.81$ for every dollar invested into the program. ${ }^{5}$ The programs reviewed have some similarities and some differences. All programs reviewed provide a dry place to sleep and a meal. The Serenity Court Homeless Medical Respite program in Philadelphia offers medication management, help accessing primary care, assistance with followup visits, and case management for social services such as health insurance and applications for assistance and residential services. ${ }^{6}$ WellSpace Health, located in California, offers suicide 
assessments, care coordination, wound care, bathing assistance, education, medication support, housing support, income assistance, behavioral health referrals, transportation, primary care and/or specialty provider while in their facility. ${ }^{7}$

The National Health Care for the Homeless Council (NHCHC) produced a documentary at a respite facility located in Boston, Massachusetts. During this documentary, clients were interviewed who had varying degrees of medical conditions when discharged from the hospital (Achilles' tendon tear, spinal cord injury, infected legs, etc.). ${ }^{8}$ Several clients stated the respite program saved their life, they could rest in peace and recover, did not have to die on the streets, and was a safe place to heal. ${ }^{8}$ A medical director in the documentary who worked for Boston Medical Center said if the medical respite program did not exist, these homeless individuals would not receive the care needed, medical conditions would return, clients would come to the hospital more ill and more often. ${ }^{8}$ Three meals a day are provided at the Barbara McInnis House in Boston, along with client support groups, arts and crafts, TV, washers and dryers, behavioral health, bingo, benefits assistance, music, computers, job support, dental and other case management services. ${ }^{9}$

\section{Hospitalization Costs Decreased}

People who experience homelessness accrue higher costs when hospitalized compared to those who do not experience homelessness. WellSpace Health, located in California, estimates that in 2018,169 of their program clients potentially saved a combined average total of $\$ 643,687.00$ by avoiding one night in the hospital each. ${ }^{7}$ A 2000 cohort study in Illinois showed an average cost of $\$ 706$ per hospital day was avoided by using medical respite care. ${ }^{10}$ The difference between the study and program could be from an estimated 18-year difference, as well as the different geographical locations. Even in countries that have universal health care such as Canada, hospitalized individuals who experience homelessness cost $\$ 2,559$ more than those who do not. ${ }^{11}$ A 2017 study showed "medical system charges for these participants decreased by $48.6 \%$ from the year prior to the year following medical respite." 12

\section{Decrease in Admissions and Inpatient Days}

This decrease in costs could be due to medical respite programs. According to a 2017 study, there was almost a 37\% decrease in admission rates and 70\% decrease in inpatient days for 29 people experiencing homelessness who were treated in a medical respite setting. ${ }^{12}$ A cohort study from 2000 showed a 49\% decrease in hospital admissions and 58\% decrease in inpatient days. ${ }^{10}$

\section{Outpatients Visits Increased}

Outpatient visits increased $192 \%$ in one study. ${ }^{12}$ These increased outpatient visits could be due to not having to worry about a meal, laundry, a place to sleep, access to social services, transportation and/or a place to recover, which have all been part of many medical respite programs across the country. Social determinants of health such as housing and income also increased for the 29 homeless individuals studied who were provided respite care following hospitalization. ${ }^{12}$

\section{Delaware}

In Delaware, not having a medical respite homeless program is a problem for people experiencing homelessness, the local health care system, and insurance companies. Last year an 
outreach team completed 2,528 screenings for people who experience homelessness for a different project and found more people who experience homelessness in Delaware than previously thought. ${ }^{13}$ A study completed in 2012 tracked 108 homeless people who, in a year, had 215 hospitalizations and in three months had 302 emergency room visits in Delaware. ${ }^{14}$ The total cost of these visits and hospitalizations was over $\$ 5.5$ million. ${ }^{14}$

The decrease in inpatient days, decrease in admissions, decrease in hospital costs, and increase outpatient visits benefits everyone. This has become a more viable option now that the State of Delaware has purchased a hotel and turned the hotel into a homeless shelter. ${ }^{15}$

\section{Current Delaware Homeless Program}

Delaware Health and Social Services (DHSS) department has one program listed on their website for homeless individuals, called the Projects for Assistance in Transition from Homelessness Program. ${ }^{16}$ This program focuses on those with mental illnesses and does not address hospital related discharges or respite care. ${ }^{16}$ Currently there is no program in the State of Delaware to support people who experience homelessness transition from the hospital if they are not sick enough to stay but too sick to be released. ${ }^{17}$ Thirty-five states and Washington D.C. are listed on the NHCHC national website that have implemented a medical respite program. ${ }^{17}$ Although programs differ, most assist in closing the gap for people who experience homelessness when discharged from the hospital but are not ready to be released back to the street or shelter. ${ }^{3}$

\section{Philadelphia, PA Compared to Wilmington, DE}

The closest medical respite program to Delaware is in Philadelphia, Pennsylvania. Geographically, the City of Wilmington and City of Philadelphia are about 40 minutes apart while driving in a car. Table 1 below shows comparable data from the United States Census between the two cities. The cities have estimated similar age demographics, housing, education, income, and poverty levels as of $2019 .{ }^{18}$

Table 1. Comparison of the Cities of Philadelphia, PA and Wilmington, $\mathrm{DE}^{18}$

$\begin{array}{lrr}\text { 2019 Data } & \text { Philadelphia, PA } & \text { Wilmington, DE } \\ \text { Age \& Gender } & & \\ \text { Person under 5 years } & 6.70 \% & 6.60 \% \\ \text { Person under 18 years } & 21.90 \% & 22.70 \% \\ \text { Person 65 years and over } & 13.40 \% & 12.90 \% \\ \text { Female } & 52.70 \% & 52.60 \% \\ \text { Race } & & \\ \text { White } & 40.70 \% & 35.60 \% \\ \text { Black or African American } & 42.10 \% & 58.30 \% \\ \text { Housing } & & \\ \text { Medium value of owned house } & \$ 163,000 & \$ 168,000 \\ \text { Median Monthly owner costs } & \$ 1,332 & \$ 1,368 \\ \text { Median Gross rent } & \$ 1,042 & \$ 1,001 \\ \text { Persons per household } & 2.55 & 2.33 \\ \text { Education } & & \end{array}$


DOI: 10.32481/djph.2021.07.017

High school grad or above over 25 yrs. age

Income

Median income

$84.70 \%$

$87.70 \%$

Per Capita income

$\$ 45,927$

$\$ 45,032$

Poverty

$\$ 27,924$

$\$ 30,238$

$24.30 \% \quad 26.00 \%$

\section{Serenity Court Homeless Medical Respite}

The Serenity Court Homeless Medical Respite program is in Philadelphia and was established in 2014. ${ }^{6}$ During the last fiscal year, Laurie Corbin, Managing Director of Community at the Philadelphia Health Management Corporation provided information that the program served 202 homeless individuals. Serenity Court Homeless Medical Respite program has 20 beds, a similar bed count to what could be done in Delaware.

\section{Delaware Medical Respite Program for Individuals Who Experience Homelessness}

The Delaware Medical Respite Program for Individuals Who Experience Homelessness (DMRPIWEH) will help provide structure to achieve the goal of a successful medical respite program. The program has several goals (see Appendix A). The first goal is staff and structure and was chosen as this is the backbone of the medical respite program. A facility, staff, policies and procedures are needed for the program to follow local ordinances, ensure clients receive treatment, and provide a safe facility for recovery.

The second goal focuses on community outreach. Many of the objectives will impact social determinants of health for individuals who experience homelessness. Mental health providers, support groups, a resource database, and assistance with obtaining access to government programs are part of the second goal. Mental health providers are needed as people who experience homelessness likely do not have access to mental health services; this will not be forced and available only if the client wants services. Support groups will be acquired not only for support for the topics discussed but will also provide social interaction that otherwise might not be something people who experience homelessness has accessible. A resource database is important both during a client's stay and when discharged, as this will allow people who experience homelessness to be set up for better success with additional resources available. Assistance with accessing government programs will allow those who are eligible to join the Supplemental Nutrition Assistance Program (SNAP) and obtain insurance to obtain access to needed services.

The third goal of DMRPIWEH is partnering with a national medical respite network. NHCHC will allow the program to have access to recommendations for programs and become searchable in the database. This is the only national database for homeless medical respite programs. Using the database will allow programs to contact other medical respite programs for best practices.

The first three goals allow for an opportunity of successful recovery for clients transitioning from the hospital. The final goal is establishing clients. People are why the program exists and building a relationship with local hospitals is the first start in obtaining client referrals. The result of these goals and objectives is to allow a proper place for people who experience homelessness to recover from hospital discharges and gain access to additional social services. 


\section{Theory}

There are several theories and models that help shape health changes, for example, theory of reasoned action/behavior health, ecological, social cognitive theory, and health belief model. ${ }^{19}$ The DMRPIWEH program uses the social-ecological model (SEM, figure 1) to show how multiple factors attribute to a person's health. ${ }^{20}$

Figure 1. Socio-Economic Model

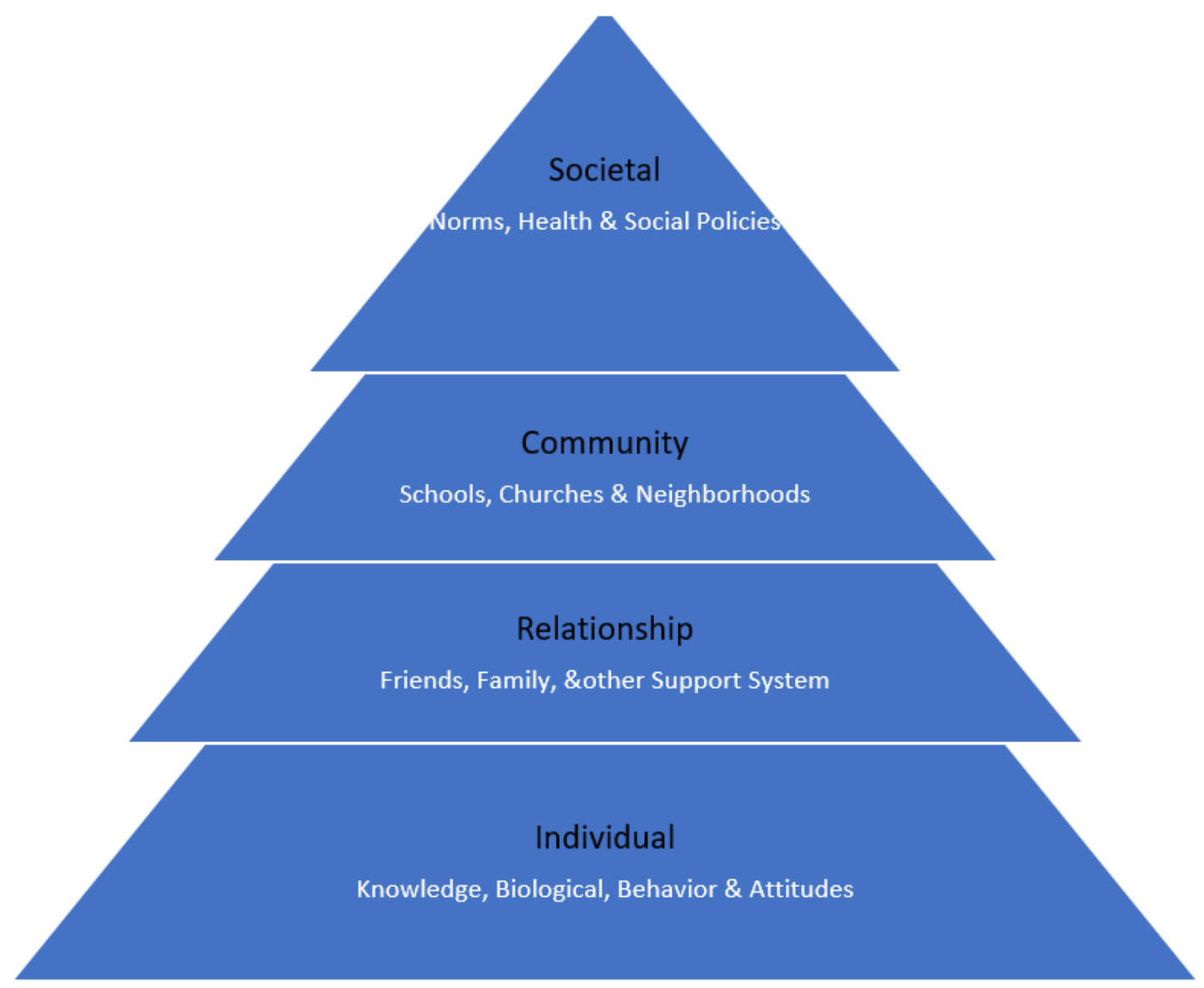

The first level of the SEM is individual. This level includes knowledge, biological, and attitudes. ${ }^{20}$ Relationship is the next level in the SEM. This level is the relationship each person forms with others such as friends and family. At the community level, places such schools, churches and neighborhoods can help mold health behaviors. The final SEM level is societal, focusing on norms and health and social policies.

The SEM was chosen because it is the best theory to assist in program development for a medical respite program for people who experience homelessness in Delaware. The individual level would include the individual's knowledge that the program exists and an understanding of what is expected of them. People who experience homelessness may have beliefs or an attitude that prevents them from wanting to participate (i.e. a person with addiction may not want - or be able to - refrain from behaviors such as drugs that are not allowed inside medical respite facilities). The program must be presented to show what knowledge could be gained and additional social services available to individuals in the program. 
The relationship level of the SEM could be a barrier to people who experience homelessness. The medical home respite program will provide support from peers while recovering from a hospital stay. The Barbara McInnis House in Boston has successful support groups in place within their program. ${ }^{9}$ Support groups like these will be offered using various topics such as housing, addiction, and mental health.

The community level can be used to address who will be eligible for the program and its services. ${ }^{21}$ Non-profits in Delaware like ChristianaCare would have eligibility requirements, provided by DMRPIWEH, for their clients to qualify. The medical respite program would work with organizations including homeless shelters, the Centers for Medicaid and Medicare, and Delaware Health and Social Services to qualify individuals for other programs after they were ready to leave the respite program. The community level brings partners into the respite medical program to provide services. This includes local residency programs to provide preventative measures including vaccines, colon cancer screenings and pap-smears. Portable mammograms will come monthly to the medical respite program to provide mammograms. Case managers will work with local health departments to assist with Supplemental Nutrition Assistance Program benefits and health insurance. Local food bank referrals and housing organizations will work with the medical respite staff to ensure services. Once discharged, the providers and case managers will ensure people who experience homelessness have a primary care provider.

The societal level of the SEM would acquire needed funding to cover program expenses. Delaware has obtained a hotel for people who experience homelessness and therefore a big expense, where to house the program, already is completed. Policies need to be in place to ensure the program is following all local and state laws regarding health and food safety, client transportation, and sustainability.

\section{Discussion}

Medical respite homes for people who experience homelessness relates to several topics that impact overall health. The topics include social determinants of health, health inequity, health promotion, and population health.

\section{Social Determinants of Health}

There are several SDOH that have an impact on lives. One is health care access and quality. ${ }^{22}$ People who experience homelessness may not have insurance or transportation to receive health care services. DMRPIWEH social service assistance will help eligible individuals apply for health insurance. Services will also be provided at the facility, therefore eliminating transportation barriers.

Economic instability is a known problem for those who experience homelessness. The social determinant of economic instability does not allow for stable housing. The longer a person experiences homelessness, health outcomes decrease. ${ }^{23}$ The medical respite program will be able to aid with SNAP application, which will assist in decreasing food related expenses. The California based medical respite program, WellSpace Health, discharged $41 \%$ of their homeless individuals to permanent or transitional housing in $2020 .^{7}$ The decrease in hospital stay time and admissions will assist with lesser medical costs. In addition, case managers will provide job announcement opportunities to clients and housing resources upon discharge. 
Neighborhood and built environments have an impact on overall health, safety, and air quality. ${ }^{22}$ People who experience homelessness endure the elements of weather, violence that may be in the streets, and pollution. The medical respite program will provide a safe, clean, and warm environment to recover from a hospital stay and resources for housing once discharged.

Social and community support is an additional social determinant of health that makes an impact in people's lives. ${ }^{22}$ People experiencing homelessness do not always stay in the same spot and although a part of society, they are distanced. Having support groups at DMRPIWEH will allow clients to have social support and a sense of community. These impacts on the SDOH will have an impact on the population health of the homeless community in Delaware. ${ }^{24}$

\section{Population Health}

People who experience homelessness are a type of population. ${ }^{24}$ This group shares similar health outcomes for an increase in inpatient days, increased costs, and increased hospital admissions. ${ }^{12}$ The medical respite programs that have been studied have proven to decrease all three of those areas. This leads to better population health for people who experience homelessness.

\section{Health Inequity}

There are several health inequities that people who experience homelessness face. Severity of disease is a health inequity that DMRPIWEH may impact. ${ }^{25}$ In Delaware, if an individual is discharged from the hospital but should not be released to the street because they are not fully recovered, there is no alternative. Readmissions then occur because the individual's initial reason for admission may not go away. Having the medical respite program allows for full recovery and therefore a decrease in readmissions and worsening symptoms. Not having access to health care also impacts severity of disease. There will be health care services offered at the facility. Resources given during discharge from DMRPIWEH will increase outpatient visits as clients will have assistance completing insurance applications and provider references.

The biggest inequity, life expectancy, is shorter for people who experience homelessness. ${ }^{23}$ DMRPIWEH will impact this disparity by allowing clients to heal in a clean environment and provide social services, both of which lead to more health care access. Preventative measures are typically less available for this population. Having preventive measures available at DMRPIWEH may lead to less severity of disease, which may lead to a longer life expectancy. ${ }^{25}$

\section{Health Promotion}

The focus of health promotion is to encourage individuals to take control of their own health. ${ }^{26}$ The DMRPIWEH will allow people who are experiencing homelessness to have the option to make their own health choices. With an unstable environment, health decisions are less of a choice as there are fewer options available. The program will be voluntary; individuals will be able to choose to better their health. People will also have a choice to accept the additional resources once in the program (support groups, preventative health, outpatient options when discharged) and apply for social service programs. This will allow individuals a say in their future health. 
DOI: $10.32481 /$ djph.2021.07.017

\section{Conclusion}

The first task of my internship was attending the Mid-Atlantic Partnership Regional Conference. ${ }^{27}$ Since I just moved back to Delaware, this helped me learn about current gaps in the region. After I watched every breakout session, I completed a gap analysis where I spent numerous hours researching gaps and programs in Delaware.

The biggest limitation I encountered was getting programs from across the country to respond with information that was usable. The national program had few data sources for access. I tried to reach the national program several times with no response. I successfully received information from a program in Philadelphia and California.

\section{References}

1. Delaware Academy of Medicine/Delaware Public Health Association. (n.d.). Community health planning \& policy development. Retrieved https://delamed.org/initiatives/publichealth/sections/community-health-planning-policy-development/

2. United States Interagency Council on Homelessness. (n.d.). Delaware homelessness statistics. Retrieved from https://www.usich.gov/homelessness-statistics/de

3. National Health Care for the Homeless Council. (2016, Oct). Standards for Medical Respite Programs. Retrieved from https://nimrc.org/wp-content/uploads/2021/04/Standards-forMedical-Respite-Programs.pdf

4. National Institute for Medical Respite Care. (2021, January). State of Medical Respite/Recuperative Care Programs. Retrieved from https://nimrc.org/wpcontent/uploads/2021/02/State-of-Medical-Respite_Recup-Care-01.2021.pdf

5. Shetler, D., \& Shepard, D. S. (2018). Medical respite for people experiencing homelessness: Financial impacts with alternative levels of medicaid coverage. Journal of Health Care for the Poor and Underserved, 29(2), 801-813. https://doi.org/10.1353/hpu.2018.0059 PubMed

6. National Health Care for the Homeless Council. (n.d.). Serenity Court homeless medical respite. Retrieved from https://nhchc.org/business-directory/245012/serenity-courthomeless-medical-respite-2/

7. Jenkins, G. (2021, Feb 14). Interim Care Program. WellSpace Health. Presentation.

8. National Health Care for the Homeless Council. (2014, Mar 10). Medical respite care for people experiencing homelessness - a short documentary [Video file]. Retrieved from https://www.youtube.com/watch?v=fUrD0-tAOSc

9. Boston Health Care for the Homeless Program. (2018 August 31). Barbara McInnis House patient FAQ. Retrieved from https://www.bhchp.org/sites/default/files/Patient\%20FAQs_8.31.2018.pdf

10. Buchanan, D., Doblin, B., Sai, T., \& Garcia, P. (2006, July). The effects of respite care for homeless patients: A cohort study. American Journal of Public Health, 96(7), 1278-1281. https://doi.org/10.2105/AJPH.2005.067850 PubMed

11. Hwang, S. W., Weaver, J., Aubry, T., \& Hoch, J. S. (2011, April). Hospital costs and length of stay among homeless patients admitted to medical, surgical, and psychiatric services. Medical Care, 49(4), 350-354. https://doi.org/10.1097/MLR.0b013e318206c50d PubMed 
12. Biederman, D. J., Gamble, J., Wilson, S., Douglas, C., \& Feigal, J. (2019, May). Health care utilization following a homeless medical respite pilot program. Public Health Nurs, 36(3), 296-302. https://doi.org/10.1111/phn.12589 PubMed

13. Landgraf, R., Holloway, S., Beaman, R., \& Fitzgerald, R. (2020, July 7). Delaware COVID19 homeless community outreach partnership 2020. Delaware Journal of Public Health, 6(2), 96-100. https://doi.org/10.32481/djph.2020.07.023

14. Delaware State Housing Authority. (2013). Delaware's plan to prevent and end homelessness. Retrieved from http://www.destatehousing.com/FormsAndInformation/Publications/plan_end_homeless.pdf

15. Cherry, A. (2020, Dec 21). Public gets opportunity to ask questions about New Castle County's hotel-turned-homeless shelter. WDEL. Retrieved from

https://www.wdel.com/news/video-public-gets-opportunity-to-ask-questions-about-newcastle-countys-hotel-turned-homeless-shelter/article a57f0dec-43ce-11eb-b9b82fbeef6ebaa8.html

16. Delaware Health and Social Services. (n.d.). Services for the homeless. Retrieved from https://dhss.delaware.gov/dhss/dsamh/homeless.html

17. National Health Care for the Homeless Council. (2020). Medical respite care directory. Retrieved from https://nhchc.org/clinical-practice/medical-respite-care/medical-respitedirectory/

18. United States Census Bureau. (n.d.). QuickFacts Philadelphia City, Pennsylvania; Wilmington City, Delaware. Retrieved from https://www.census.gov/quickfacts/fact/table/philadelphiacitypennsylvania,wilmingtoncityd elaware/PST045219

19. Rural Health Information Hub. (n.d.). Ecological models - rural health promotion and disease prevention toolkit. Retrieved from https:/www.ruralhealthinfo.org/toolkits/healthpromotion/2/theories-and-models/ecological

20. Centers for Disease Control and Prevention. (2021, Jan 28). the social-ecological model: a framework for prevention. Retrieved from https://www.cdc.gov/violenceprevention/about/social-ecologicalmodel.html

21. National Health Care for the Homeless Council. (2016a, April). Using the Social Ecological Model to examine how homelessness is defined and managed in rural East Tennessee. Retrieved from https://nhchc.org/wp-content/uploads/2019/08/rural-homelessness-report_nhchcpublication.pdf

22. U.S. Department of Health and Human Services. (n.d.). Social determinants of health. Retrieved from https://health.gov/healthypeople/objectives-and-data/social-determinantshealth

23. Stafford, A., \& Wood, L. (2017, December 8). Tackling health disparities for people who are homeless? Start with social determinants. International Journal of Environmental Research and Public Health, 14(12), 1535. https://doi.org/10.3390/ijerph14121535 PubMed 
24. Silverstein, M., Hsu, H. E., \& Bell, A. (2019, December 24). Addressing social determinants to improve population health. JAMA, 322(24), 2379-2380. https://doi.org/10.1001/jama.2019.18055 PubMed

25. Centers for Disease Control and Prevention. (2020, Mar 11). Health equity. Retrieved from https://www.cdc.gov/chronicdisease/healthequity/index.htm

26. World Health Organization. (n.d.). Health promotion. Retrieved from https://www.who.int/westernpacific/health-topics/health-promotion

27. Mid-Atlantic Public Health Partnership. (2021). Empowering communities to address the social determinants of health. Retrieved from https://midlantic.org/ 
DOI: $10.32481 / \mathrm{djph} .2021 .07 .017$

\section{Appendix A}

Delaware Medical Respite Program for Individuals who Experience Homelessness Logic Model

\begin{tabular}{|c|c|c|c|c|c|}
\hline Goal & & $\begin{array}{l}\text { Implementation } \\
\text { Activities/Objectiv } \\
\text { es }\end{array}$ & $\begin{array}{l}\text { Short Term } \\
\text { Deliverables }\end{array}$ & $\begin{array}{l}\text { Mid Term } \\
\text { Outputs }\end{array}$ & $\begin{array}{l}\text { Long Term } \\
\text { Outcomes }\end{array}$ \\
\hline \multirow[t]{3}{*}{$\begin{array}{l}\text { Staff and } \\
\text { Structure }\end{array}$} & 1 & $\begin{array}{l}\text { Determine } \\
\text { appropriate } \\
\text { facility to house } \\
\text { program }\end{array}$ & $\begin{array}{l}\text { Reach out to } \\
\text { State of DE to } \\
\text { discuss use of } \\
\text { Hope Center } \\
\text { (May 2021) }\end{array}$ & $\begin{array}{l}\text { Obtain } \\
\text { additional } \\
\text { permits for } \\
\text { Hope Center } \\
\text { OR } \\
\text { determine } \\
\text { back up } \\
\text { facility } \\
\text { (June 2021) }\end{array}$ & $\begin{array}{l}\text { Move-in to } \\
\text { chosen facility } \\
\text { (July 2021) }\end{array}$ \\
\hline & 2 & $\begin{array}{l}\text { Obtain staff (i.e., } \\
\text { mental health } \\
\text { providers, nurse, } \\
\text { social workers, } \\
\text { etc.) }\end{array}$ & $\begin{array}{l}\text { Post job } \\
\text { announcemen } \\
t \text { with State of } \\
\text { Delaware } \\
\text { (May 2021) }\end{array}$ & $\begin{array}{l}\text { Interview } \\
\text { potential } \\
\text { candidates } \\
\text { (June 2021) }\end{array}$ & $\begin{array}{l}\text { All staff } \\
\text { positions filled } \\
\text { (July 2021) }\end{array}$ \\
\hline & 3 & $\begin{array}{l}\text { Create policies } \\
\text { and procedures } \\
\text { for DMRPIWEH }\end{array}$ & $\begin{array}{l}\text { Download } \\
\text { suggestions } \\
\text { from National } \\
\text { Institute for } \\
\text { Medical } \\
\text { Respite Care } \\
\text { (May 2021) }\end{array}$ & $\begin{array}{l}\text { Edit policies } \\
\text { and } \\
\text { procedures } \\
\text { based on } \\
\text { Delaware } \\
\text { law and } \\
\text { program } \\
\text { objectives } \\
\text { (June 2021) }\end{array}$ & $\begin{array}{l}\text { Policies and } \\
\text { procedures } \\
\text { modified as } \\
\text { needed to reflect } \\
\text { new } \\
\text { rules/regulations } \\
\text { (ongoing) }\end{array}$ \\
\hline $\begin{array}{l}\text { Communit } \\
\text { y } \\
\text { Outreach }\end{array}$ & 1 & $\begin{array}{l}\text { Establish a list of } \\
\text { mental health } \\
\text { providers in the } \\
\text { State who will } \\
\text { accept clients after } \\
\text { discharge from } \\
\text { DMRPIWEH }\end{array}$ & $\begin{array}{l}\text { Reach out to } \\
\text { the State of } \\
\text { Delaware } \\
\text { and current } \\
\text { mental } \\
\text { health } \\
\text { programs for } \\
\text { a list of } \\
\text { providers } \\
\text { (May 2021) }\end{array}$ & $\begin{array}{l}\text { Clients } \\
\text { are } \\
\text { referred } \\
\text { to } \\
\text { provider } \\
\text { s after } \\
\text { discharg } \\
\text { e (Sept } \\
\text { 2021) }\end{array}$ & $\begin{array}{l}\text { Referral list is } \\
\text { updated as } \\
\text { needed } \\
\text { (ongoing) }\end{array}$ \\
\hline
\end{tabular}


DOI: 10.32481/djph.2021.07.017

\begin{tabular}{|c|c|c|c|c|c|}
\hline & 2 & $\begin{array}{l}\text { Social work staff } \\
\text { create support } \\
\text { groups for clients }\end{array}$ & $\begin{array}{l}25 \% \text { of } \\
\text { clients are } \\
\text { invited to } \\
\text { join support } \\
\text { groups } \\
\text { within the } \\
\text { program } \\
\text { (Aug 2021) }\end{array}$ & $\begin{array}{l}60 \% \text { of } \\
\text { clients } \\
\text { are } \\
\text { involved } \\
\text { in } \\
\text { ongoing } \\
\text { support } \\
\text { groups } \\
\text { (Oct } \\
2021 \text { ) }\end{array}$ & $\begin{array}{l}100 \% \text { of clients } \\
\text { are involved in } \\
\text { ongoing support } \\
\text { groups (Jan } \\
2022 \text { ) }\end{array}$ \\
\hline & 3 & $\begin{array}{l}\text { Obtain database } \\
\text { for resources }\end{array}$ & $\begin{array}{l}\text { Identify } \\
\text { database } \\
\text { program } \\
\text { (May 2021) }\end{array}$ & $\begin{array}{l}\text { Social } \\
\text { Worker/Cas } \\
\text { e Managers } \\
\text { obtain } \\
\text { resources in } \\
\text { community } \\
\text { (Aug 2021) }\end{array}$ & $\begin{array}{l}100 \% \text { of clients } \\
\text { have needed } \\
\text { resources/referral } \\
\text { s when } \\
\text { discharged (Sept } \\
2021 \text { ) }\end{array}$ \\
\hline & 4 & $\begin{array}{l}\text { Assist individuals } \\
\text { in obtaining access } \\
\text { to government } \\
\text { programs }\end{array}$ & $\begin{array}{l}\text { Social } \\
\text { Worker(s)/Cas } \\
\text { e Manager(s) } \\
\text { trained to } \\
\text { complete } \\
\text { SNAP benefit } \\
\text { applications } \\
\text { for eligible } \\
\text { clients (Aug } \\
\text { 2021) }\end{array}$ & $\begin{array}{l}\text { Eligible } \\
\text { clients are } \\
\text { enrolled in } \\
\text { Medicaid } \\
\text { and } \\
\text { Medicare } \\
\text { (Sept } \\
2021)\end{array}$ & $\begin{array}{l}\text { Eligible clients } \\
\text { are enrolled in } \\
\text { housing } \\
\text { assistance (Oct } \\
2021)\end{array}$ \\
\hline $\begin{array}{l}\text { Partner } \\
\text { with } \\
\text { National } \\
\text { Network }\end{array}$ & 1 & $\begin{array}{l}\text { Access other } \\
\text { medical respite } \\
\text { programs \& } \\
\text { DMRPIWEH } \\
\text { placed in national } \\
\text { registry }\end{array}$ & $\begin{array}{l}\text { Contact } \\
\text { National } \\
\text { Institute for } \\
\text { Medical } \\
\text { Respite Care } \\
\text { to discuss } \\
\text { program } \\
\text { (May 2021) }\end{array}$ & $\begin{array}{l}\text { Complete } \\
\text { forms for } \\
\text { National } \\
\text { Institute } \\
\text { for } \\
\text { Medical } \\
\text { Respite } \\
\text { Care } \\
\text { database } \\
\text { (June } \\
\text { 2021) }\end{array}$ & $\begin{array}{l}\text { Contact other } \\
\text { medical respite } \\
\text { programs for } \\
\text { best practices } \\
\text { (July 2021) }\end{array}$ \\
\hline $\begin{array}{l}\text { Establish } \\
\text { Clients }\end{array}$ & 1 & $\begin{array}{l}\text { Receive referrals } \\
\text { from hospitals }\end{array}$ & $\begin{array}{l}\text { Choose } \\
\text { hospitals for } \\
\text { DMRPIWEH }\end{array}$ & $\begin{array}{l}\text { Meet } \\
\text { with } \\
\text { hospital } \\
\text { leadershi }\end{array}$ & $\begin{array}{l}\text { Clients referred } \\
\text { to program (Aug } \\
\text { 2021) }\end{array}$ \\
\hline
\end{tabular}


DOI: $10.32481 / \mathrm{djph} .2021 .07 .017$

\begin{tabular}{|l|l|l|l|l|l|}
\hline & & $\begin{array}{l}\text { program } \\
\text { (May 2021) }\end{array}$ & $\begin{array}{l}\mathrm{p} \text { (June } \\
\text { 2021) }\end{array}$ & \\
& & & \\
\hline
\end{tabular}

Copyright (c) 2021 Delaware Academy of Medicine / Delaware Public Health Association.

This is an Open Access article distributed under the terms of the Creative Commons Attribution Non-Commercial License (https://creativecommons.org/licenses/by-nc-nd/4.0/) which permits unrestricted non-commercial use, distribution, and reproduction in any medium, provided the original work is properly cited. 